\title{
Future machine-readable cataloguing format for South African libraries
}

\author{
M.M.M. Snyman \\ Department of Library and Information Studies, Technikon Pretoria, Private Bag X680, Pretoria, 0001 Republic of South Africa \\ Snyman@cis.co.za
}

Received May 1997; accepted June 1997

\begin{abstract}
A South African Machine-Readable Cataloguing (SAMARC) format based on UNIMARC was developed in the late 1970s. Since its inception SAMARC has been used extensively as national exchange format within the South African information community. However, due to various factors a need has arisen to clarify the future of SAMARC. Initiated by the Interim Committee for Bibliographic Organisation (ICBO), an investigation was undertaken to determine whether UNIMARC or USMARC should replace SAMARC, or whether the latter should be retained. SAMARC, UNIMARC and USMARC were compared regarding scope, purpose, updating, technical aspects, current status, strengths and weaknesses. Various scenarios were drawn up and the implications of each scenario for the various stakeholders were investigated. A cost benefit study was also included to evaluate the cost of conversion as well as the cost-effectiveness over the long term. Based on the information obtained, various recommendations were made regarding a future MARC format for South Africa. The report of the investigation was submitted to ICBO and all delegates attending a seminar on a future MARC format for South Africa, which was held in Pretoria on 24 and 25 April 1997. The decisions and conclusions of the seminar are also included in the article.
\end{abstract}

\begin{abstract}
'n Suid-Afrikaanse Masjien-leesbare Katalogiseringsformaat (SAMARC), gebaseer op UNIMARC, is in the laat 1970's ontwikkel. Sedert die ontstaan daarvan is SAMARC op groot skaal gebruik as nasionale uitruilformaat in die SuidAfrikaanse inligtingsgemeenskap. As gevolg van verskeie faktore het daar egter 'n behoefte ontstaan om die toekoms van SAMARC uit te klaar. In opdrag van die Interim Committee for Bibliographic Organisation (ICBO) is ondersoek ingestel na die wenslikheid om SAMARC te behou of om dit te vervang met UNIMARC of USMARC. SAMARC, UNIMARC en USMARC is vergelyk ten opsigte van omvang, doel, opdatering, tegniese aspekte, huidige status, swak- en sterkpunte. Verskeie scenarios is voorgestel en die implikasies van elke scenario vir die verskillende rolspelers is ondersoek. 'n Kostevoordeelstudie is ook ingesluit ten einde die koste van omskakeling sowel as die koste-effektiwiteit oor die lang termyn te bepaal. Aan die hand van die inligting ingewin, is verskeie aanbevelings gedoen oor ' $n$ toekomstige MARC-formaat vir Suid-Afrika. Die verslag van die ondersoek is voorgelê aan ICBO sowel as aan die afgevaardigdes van 'n seminaar oor 'n toekomstige MARC-formaat vir Suid-Afrikaanse biblioteke wat op 24 en 25 April 1997 in Pretoria gehou is. Die besluite wat geneem is tydens die seminaar en die gevolgtrekkings wat gemaak is, is ingesluit in die artikel.
\end{abstract}

\section{Background information}

In the 1960s the Library of Congress decided to computerize its own cataloguing procedures and to supply a computerized cataloguing service to other libraries. In doing so the Library of Congress created a Machine-Readable Cataloguing (MARC) format for catalogue records that could be interpreted by a computer. The format, known as LCMARC (later as USMARC) had considerable impact on the development of computerized library and information services, co-operative cataloguing and library networks.

It was now possible to exchange bibliographic descriptions in a machine-readable form between various computerized library systems, because the MARC format served as a common format, which is a prerequisite for such exchanges. The MARC format as used in the United States, served as a basis for the development of similar formats in other countries. For various reasons each country saw fit to adapt the LCMARC format to local conditions and needs. Examples are BNBMARC which developed into UKMARC, CANMARC and AUSMARC. Thirty national MARC formats exist throughout the world, many of which are based on either USMARC or UKMARC (Kokabi 1995:22).

With the proliferation of national formats and increasing record exchange activities with growing conversion diffi- culties, the International Association of Library Associations and Institutions (IFLA) appointed a working group to develop a comprehensive universal exchange format that encompassed universal format requirements, and that provided a high level of compatibility with existing national formats. The result was the development of an international version of MARC (called UNIMARC) in 1977, nine years after the creation of LCMARC. Countries could use UNIMARC as a standard on which they could base their own format. Regrettably it was too late to have it adopted as the only exchange format, as too many applications were already using LCMARC or one of the other formats.

A South African MARC format, known as SAMARC and based on UNIMARC, was developed in the late 1970s by order of the National Library Advisory Committee. Since its inception SAMARC has been used extensively as exchange format within the South African library community. The format was also implemented as the base format for various commercial and in-house library systems.

After 17 years a need has arisen to clarify the future of SAMARC. The political transformation in South Africa has led to the re-establishment of normal relations with just about every country in the world. This presents opportunities for access to the world's information sources as well as the 
exchange of bibliographic records. Dwindling resources and the spiralling costs forced libraries to find ways of cooperating in the most effective way. Cost-effective cooperation requires the use of a common exchange format to support common understanding and the processing of the records received. Libraries realize that the more they conform to an international standard, the cheaper and more efficient the downloading of records will be. The rapid improvement of information technology also has implications for a MARC format for South Africa. South African libraries realize that they have to capitalize on the advances in information technology to bring more information, to more people, in a shorter time. Other factors which have led to the questioning of the suitability of SAMARC, include, among others, the cost of maintaining it and the inability of SAMARC to keep pace with the new requirements of the South African information community. The possible unification of the library and information associations of South Africa could also have an impact on the maintenance and further development of SAMARC. Presently the editor of SAMARC is assisted by the SAMARC Subcommittee of the South African Institute for Librarianship and Information Science (SAILIS).

For these and several other reasons, an investigation, initiated by the Interim Committee for Bibliographic Organisation (ICBO), was undertaken to determine whether UNIMARC or USMARC should replace SAMARC, or whether the latter should be retained. The report of the investigation was submitted to ICBO and all delegates attending a seminar on a future MARC format for South African libraries held in Pretoria on 24 and 25 April 1997. This article is an abstract of the results of the investigation. It also includes the decisions taken and conclusions reached during the seminar.

\section{Methodology}

Various stakeholders who could be influenced by the change of the MARC format, were identified. These include:

- South African libraries and information centres with computerized catalogues based on SAMARC; that utilize the facilities of Sabinet Online; and that are interested in co-operative acquisition and cataloguing, online searching, resource sharing and the downloading of records.

- Sabinet Online, of which the main databases are standardized according to SAMARC.

- South African-based system vendors who supply and support various library and information management systems based on a MARC format.

Data was collected by means of

- The study of relevant documentation (inter alia recent subject literature pertaining to the three MARC formats, correspondence about the subject, minutes of meetings of relevant bodies, et cetera) and details obtained by means of written responses to questions stated in letters to various officials, system vendors and persons involved in the various South African consortia.
- Face-to-face and telephonic interviews with system vendors, librarians, staff members of Sabinet Online and the editor of SAMARC.

- A questionnaire distributed via Sabilist and LibraryNet to determine inter alia the country from which most of the information sources in South African libraries are currently obtained.

SAMARC, UNIMARC and USMARC were compared regarding scope, purpose, updating, technical aspects, current status, strengths and weaknesses. Three scenarios were drawn up.

- SAMARC is retained as national exchange format.

- UNIMARC replaces SAMARC as exchange format.

- USMARC replaces SAMARC as exchange format.

The implications of each scenario for the various stakeholders were investigated, as well as the processes that should be followed for the effective use of the format. A cost benefit study was also included to evaluate the cost of conversion as well as the cost-effectiveness over the long term. Based on the information obtained, various recommendations were made regarding a future MARC format for South African libraries.

\section{Research findings}

\section{Comparison: SAMARC, UNIMARC and USMARC}

Comparing SAMARC, UNIMARC and USMARC regarding scope, purpose, updating, technical aspects, current status, strengths and weaknesses, the following conclusions were reached:

\section{Scope and purpose}

SAMARC is the accepted South African standard record format for the exchange of bibliographic data in machinereadable form between libraries and information centres in South and Southern Africa. It is not intended to be used for the exchange of authority records. A SAMARC authority format still has to be developed to cater for the effective exchange of authority records.

UNIMARC is the format IFLA developed and approved for the international exchange of bibliographic and authority data in machine-readable form. Formats exist for bibliographic and authority records. UNIMARC, although adopted as a national format in many countries, was designed primarily as an exchange format to accommodate different standards for bibliographic input and to cater for all the idiosyncrasies of existing national formats. The UNIMARC/Authorities also enables the international exchange of authority data in machine-readable form.

USMARC is the collective name for the various MARC communication formats in the United States. USMARC formats are defined for bibliographic, authority and holdings/ locations data as well as community information and classification data. The USMARC format for bibliographic data is designed to hold bibliographic records for books, serials, archival and manuscripts materials, computer files, maps, 
music and visual materials (including artefacts, kits and audiovisual items). It represents an integrated format for the identification and description of different forms of bibliographic materials (Gredley \& Hopkinson 1990:153). The USMARC format for authority data has been created to allow specific data in an authority record to be identified for machine manipulation. The authority format allows authority records to be exchanged without the need to also exchange bibliographic records. It therefore facilitates the independent exchange of authority data (Gredley \& Hopkinson 1990:158). The USMARC format for holdings data contains the specification for encoding data elements pertinent to holdings and location of all forms of material. The format is designed to be used independently (Gredley \& Hopkinson 1990:160). The USMARC format for community information allows the description of programmes, services, organizations, individuals, et cetera about which people in a community might want information (Bruns 1992:387). The USMARC format for classification data contains specifications for the conversion of classification data in machine-readable form. It allows the communication of classification records between systems and provides for the storage of classification data in the computer. Both the Library of Congress Classification (LCC) and the Dewey Decimal Classification (DDC) are accommodated in the format (Guenther 1994:199-202).

From the description above it is quite clear that SAMARC is a format for the exchange of bibliographic data, while UNIMARC and USMARC also provide for the exchange of other types of data. Both UNIMARC and USMARC have developed an exchange format for authority data. USMARC has gone even further by developing formats for holdings/ locations data, community information and classification data.

\section{Updating}

In March 1980 the first edition of SAMARC: South African national format for the exchange of machine-readable bibliographic descriptions was published by the National Library Advisory Council of South Africa. The first edition (corrected) was published in 1982. Since 1982, the revision of the SAMARC format has become the responsibility of the Committee for Bibliographic Control of SAILIS. The second, revised edition was made available in draft form by the State Library in 1993 under the title SAMARC manual and was distributed to a number of cataloguers during a SAMARC Workshop. The SAMARC manual has been further revised and published in 1995.

There is no proper infrastructure for the regular updating of SAMARC. Updating is done on a part-time basis with the assistance of the SAMARC Working Group appointed by the Subcommittee for Bibliographic Standards of the Committee for Bibliographic Control of SAILIS.

Both UNIMARC and USMARC are subject to continuous revision and they both have a proper infrastructure for the updating and maintenance of their formats. The Permanent UNIMARC Committee (PUC), established in 1991, is in charge of the maintenance, revision and promotion of the UNIMARC format. PUC accepts ideas for review and/or updating from any source. After careful examination and discussion, those proposals considered as consistent and of priority are approved at PUC meetings, held once a year. Approved changes, updates and specifications are usually published within six to nine months after the PUC meeting at which approval took place. These eventually take the form of 'UNIMARC documentation updates' and are distributed through the IFLA UBCIM programme and advertised in International cataloguing \& bibliographic control (ICBC), a quarterly journal of the IFLA UBCIM programme (Permanent UNIMARC Committee 1992:51-52).

The responsibility for reviewing and revising the USMARC formats rests jointly with the Machine-Readable Bibliographic Information Committee (MARBI) and the USMARC Advisory Group. MARBI is a committee of the American Library Association (ALA), and is composed of three representatives from each of the three functionorientated divisions of ALA, namely the Association for Library Collections and Technical Services (ALCTS), Library and Information Technology Association (LITA) and the Reference and Adult Services Division (RASD). The USMARC Advisory Committee is composed of representatives from the national libraries, bibliographic utilities, vendor groups and other library and scholarly associations. Proposals for changes in formats and other matters for discussion are submitted to joint meetings of MARBI and the USMARC Advisory Group at each ALA conference (annual and midwinter). The USMARC is updated twice a year and amendments and changes are regularly reported in the Library of Congress information bulletins and in USMARC format: proposed changes, available on subscription from the Library of Congress (Furrie 1994:10).

\section{Technical aspects}

The formats (SAMARC, UNIMARC, UNIMARC/Authorities and the various USMARC formats) consist of three elements, namely record structure, content designation and data content of the record.

Due to the connection of all three formats with ISO 2709 , there is a similarity between the formats with regard to structure and content designation. Regarding content, it was clear from the comparison of the bibliographic formats that SAMARC and UNIMARC are closely related in technical terms and that there are considerable technical differences between SAMARC and UNIMARC on the one side, and USMARC on the other side. Some of the differences in the functional blocks are reflected in Table 1 .

SAMARC and UNIMARC on the one hand and USMARC on the other hand, use a number of identical tags for different purposes, for example field 300 in SAMARC and UNIMARC is defined for notes, while in USMARC it is used for physical description.

SAMARC, UNIMARC and USMARC classify 'access points' into two groups, namely main entries and added 
Table 1 Comparison of the functional blocks of the SAMARC, UNIMARC and USMARC bibliographic formats

\begin{tabular}{llll}
\hline \multicolumn{2}{c}{ SAMARC and UNIMARC } & & \multicolumn{1}{c}{ USMARC } \\
\hline $0 x x$ & Identification & $0 x x$ & Numbers \& codes \\
$1 \times x$ & Coded information & $1 \times x$ & Main entries \\
$2 x x$ & Description & $2 x x$ & Description - title \& title-related fields, edition, etc. \\
$3 x x$ & Notes & $3 x x$ & Physical description \\
$4 x x$ & Links & $4 x x$ & Series \\
$5 x x$ & Variant title & $5 x x$ & Notes \\
$6 x x$ & Subjects & $6 x x$ & Subjects \\
$7 x x$ & Responsibility (primary, alternative & $70 x-75 x$ & Added entries \\
& secondary) & & \\
& & $76 x-78 x$ & Links \\
$8 x x$ & Agency information & $80 x-840$ & Series added entries \\
& & $841-88 x$ & Holdings, etc. \\
$9 x x$ & Local use & $9 x x$ & Local use \\
\hline
\end{tabular}

entries. However, the way SAMARC and UNIMARC handle these 'access points' differs from the way it is dealt with by USMARC. In SAMARC and UNIMARC the main entries are supplied by primary (intellectual) responsibility fields in the $7 \mathrm{xx}$ area, plus the title and uniform title statement fields in the 200 and 500 fields. Added entries are: variant/related title block area $(5 x x)$, series area $(4 x x)$, subject heading area $(6 x x)$ and alternative/secondary intellectual responsibility fields in the $7 \mathrm{xx}$ area.

In USMARC the main entries are in $1 \mathrm{xx}$, for example 100 (Personal name), 110 (Corporate name), 111 (Meeting name) and 130 (Uniform title). The added entries are mostly in the x00, x10, x11, x30, x40, x50 areas, for example:

600 (Subject added entry - Personal name)

610 (Subject added entry - Corporate name)

611 (Subject added entry - Meeting name)

630 (Subject added entry - Uniform title)

650 (Subject added entry - Topical name)

700 (Added entry - Personal name)

710 (Added entry - Corporate name)

711 (Added entry - Meeting name)

730 (Added entry - Uniform title)

In contrast to UNIMARC and USMARC, SAMARC does not have an authority format. From the comparison of the basic record structure of UNIMARC/Authorities and the USMARC format for authority data, it was clear that they are closely related regarding structure. This is illustrated in the following example:

UNIMARC label: $\quad$ 00350nxbbb2200061bbb45bb

USMARC leader: $\quad 00350 n z b b b 2200061$ nbb4500
There are differences in the number of functional blocks as well as the meaning of some of the tags. These differences can clearly be seen in Table 2 .

In the UNIMARC format forenames are separately subfielded while this is not the case with USMARC, for example:

UNIMARC: 200 b1\$aGray\$bStephen\$f1941-

USMARC: $10010 \neq$ aGray, $\quad$ Stephen, $\neq$ d1941-

Another interesting difference, as seen in the following example, is that USMARC defines two separate field types for headings for corporate bodies and conferences (meetings) (tags $\times 10$ and $\times 11$ ). UNIMARC collapses these into a single field ( $x 10)$ whose character is then specified by the first indicator. The first indicator $(0=$ Corporate name, $1=$ Meeting name) specifies whether it is a corporate name or conference (meeting). The second indicator specifies the entry order of the elements in a name and is analogous to the first indicator of USMARC's $x 10$ and $\times 11$, for example:

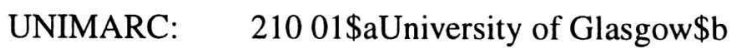

Centre for Whistler Studies

210 12\$aInternational Conference on

Automatic Image Processing

USMARC: $\quad 11010 \neq a$ University of Glasgow $\neq b$

Centre for Whistler Studies

$11120 \neq$ aInternational Conference on

Automatic Image Processing

As mentioned previously, USMARC has additional formats, namely for holdings data, community information and classification data, which do not apply to SAMARC and UNIMARC. 
Table 2 Comparison between the functional blocks of UNIMARC/Authorities and the USMARC format for authority data

\begin{tabular}{|c|c|c|c|}
\hline & UNIMARC/Authorities & & USMARC format - authorities \\
\hline $0 x x$ & Identification block & $0 \mathrm{xx}$ & $\begin{array}{l}\text { Control information, identification and classification } \\
\text { numbers }\end{array}$ \\
\hline $\operatorname{lxx}$ & Coded information block & $1 x x$ & Headings (established and unestablished) \\
\hline $2 x x$ & Heading block & $2 x x$ & Complex 'see' references \\
\hline $3 x x$ & $\begin{array}{l}\text { Information note block (notes intended for } \\
\text { public display) }\end{array}$ & $3 x x$ & Complex 'see also' references \\
\hline $4 x x$ & See reference tracing block & $4 \times x$ & 'see from' tracings \\
\hline $5 \mathrm{xx}$ & See also reference tracing block & $5 \times x$ & 'see also from' tracings \\
\hline $6 \times x$ & Classification number block & $6 x x$ & Series treatment decisions, notes, etc. \\
\hline $7 x x$ & Linking heading block & & \\
\hline $8 \mathrm{xx}$ & Source information block & & \\
\hline $9 x x$ & National (i.e. local) use block & $9 \mathrm{xx}$ & Reserved for local implementation \\
\hline
\end{tabular}

\section{Current status}

SAMARC is used extensively as national exchange format within the South African library community. Only seven of the 33 respondents to the questionnaire do not use SAMARC. The format also serves as a base format for various commercial and in-house library systems in South Africa. Basic training in SAMARC is provided by ten universities and three technikons (Coetzee 1995:156-157). The bibliographic descriptions in the main databases of Sabinet Online are standardized according to SAMARC. Sabinet Online also adds entries to SACat by incorporating bibliographic descriptions (mainly from the Library of Congress and the British Library) which are already available internationally in MARC format (USMARC and UKMARC). A conversion program has been developed by Sabinet Online for the conversion of the records from USMARC to SAMARC. Until recently no conversion program for the conversion of SAMARC records to USMARC existed. However, during the seminar Sabinet Online announced that they are busy developing and testing such a conversion program. Due to the availability of South African records only in SAMARC, libraries using USMARC are not interested in obtaining South African records. For these libraries the development of a separate conversion programme is not worth the effort since the number of records that may be of use to them is relatively small.

UNIMARC enjoys widespread support in Europe, Asia and parts of Latin America (McKercher \& Chang 1995:21). From a study conducted by Campos, Lopes and Galvao (1995:445459 ) it became clear that, at the level of national bibliographic services, UNIMARC is achieving significant use in Europe as a national and exchange format. As far as library networks in Europe are concerned, UNIMARC is the most used exchange format, followed by USMARC. Library systems currently used or available in Europe also show a good level of support for UNIMARC, along with USMARC and UKMARC. UNIMARC is also the preferred format for projects funded by the European Commission. In the USEMarcon project, a software package capable of converting bibliographic records from any MARC format into any other MARC format, UNIMARC serves as the central conversion format (Campos, Lopes \& Galvao 1995:447).

The USMARC format is in use worldwide and it is still gaining ground. Just recently Australia and Thailand have changed to USMARC. Regarding library systems in Europe, support is in favour of USMARC followed by UKMARC and UNIMARC (Campos, Lopes \& Galvao 1995:455-458). USMARC is also the base format for North American commercial systems; national bibliographic utilities such as the Online Computer Library Center (OCLC) and Research Library Information Network (RLIN) and the prescribed core bibliographic records for different types of library materials. USMARC plays an important role in the harmonization of USMARC, CANMARC and UKMARC, as well as in the Name Authority Co-operative (NACO) and the Subject Authority Co-operative (SACO) which facilitate the standard form of headings and which results in the consistent use of authority headings in bibliographic records by cataloguers worldwide. OCLC is also in the midst of developing a conversion facility between UNIMARC and USMARC and vice versa. The aim is to batchload UNIMARC records into WorldCat, the OCLC online union catalogue.

In contrast to UNIMARC, various utilities are available for USMARC, many of which are available as freeware. USMARC has a field for Uniform Resource Locators (URLs) and the concise versions of the various USMARC formats are available on the Internet. UNIMARC is still behind regarding the recording of materials on the Internet. 


\section{Strengths and weaknesses}

As a national exchange format, SAMARC satisfies the specific needs of the South African community, for example it provides for the cataloguing of multi-lingual material. However, SAMARC does not keep pace with the new requirements of the South African libraries. Although a need was expressed at various occasions for an authority and holdings format, these formats do not exist in SAMARC. It also does not cater for the description of electronic resources and the accommodation of the International Standard Music Number.

UNIMARC has been developed by representatives from organizations and national cataloguing committees of 16 countries. Most of the representatives involved in developing UNIMARC are experts on their national MARC formats. McCallum (Majumder 1992:19) of the Library of Congress rightly observed that 'UNIMARC was not simply an adoption of one group's format but a true international effort'. UNIMARC appears to be a good standard, providing both a bibliographic and an authority format that are totally compatible and linkable. An important aspect of UNIMARC is its stability and flexibility. The existing UNIMARC structure should remain relatively stable. The structure is more flexible than that of the other MARC formats, especially in the encoding of access points and the interrelation between separate records of various categories (Varniené 1995:9). UNIMARC is specifically designed to handle multi-lingual materials and this feature is particularly useful in countries where different languages are not unusual (Kokabi 1995:10).

However, as an international format, UNIMARC has to cater for all the idiosyncrasies of existing national formats. For this reason, the UNIMARC format contains some redundancy. A certain amount of overlap exists between uniform titles, collective uniform titles, uniform conventional headings and topical names used as subjects (Gredley \& Hopkinson 1990:193).

USMARC cataloguing records are available worldwide. This facilitates shared cataloguing and eliminates duplication of effort. USMARC includes more detailed information and covers a more comprehensive data environment. It also keeps pace with the needs and demands of the library community. As mentioned previously, USMARC has a field for URLs in order to record material on the Internet.

On the negative side the USMARC formats have a large degree of redundancy. The redundancy is uneconomical and leads to unnecessary complexity. According to Leazar (1992: 202) the redundancy is in many cases a pure repetition of data present elsewhere. As the integration of the bibliographic formats only occurred in the past few years, it may happen that problems might occur for which there is no immediate solution. Many of the valuable links that UNIMARC seeks to establish are not presently coded in the USMARC records. In contrast to UNIMARC and SAMARC, USMARC does not cater for the multi-lingual nature of library and information communities.

\section{Scenarios}

For each of the three proposed scenarios the implications for the various stakeholders were spelled out, as well as the processes that should be followed for the effective use of the format. The financial implications were also investigated.

Should SAMARC be retained, libraries will continue with their activities as usual. However, for SAMARC to keep pace with international developments and the requirements of South African libraries, additional formats will have to be developed and provision will have to be made for the recording of electronic materials. The updating will have to take place on a regular basis, and for this purpose a SAMARC office will be required with a full-time qualified staff member, supported by a group of experts. The main databases of Sabinet Online continue to be standardized according to SAMARC, and Sabinet Online continues to convert USMARC records to SAMARC for inclusion in SACAT. SAMARC continues to be the base format for South African library systems. However, the system vendors will be expected to keep track of all the new developments and changes which inevitably have to take place should SAMARC be retained as national exchange format.

If UNIMARC or USMARC should replace SAMARC as national exchange format, conversion programs (SAMARC to UNIMARC and vice versa, or SAMARC to USMARC) will have to be created. Although hardware will not have to be replaced, library and information systems will have to be adapted to accommodate either UNIMARC or USMARC. Retrospective conversion of records will have to take place regardless of whether libraries continue with SAMARC in the interim or changeover to UNIMARC or USMARC immediately. Very close co-operation between Sabinet Online and its users will be required to ensure consistency of applying the UNIMARC/Authorities or the various USMARC formats on previous SAMARC records. Sabinet Online will have to make provision for an interim period in which their member libraries can add or download records in either the alternative MARC formats or SAMARC, as not all libraries will be able to switch to UNIMARC or USMARC immediately. A South African-based MARC office will have to be established to serve, inter alia, as central co-ordinating point for receiving and distributing information on changes and amendments to UNIMARC or USMARC, for training in the new format and for receiving and relaying of proposals from the South African library community to the Permanent UNIMARC Committee (PUC) or the Network Development and MARC Standard Office for incorporation in either UNIMARC or USMARC. One qualified staffmember should be appointed on a part-time basis. South African system vendors may experience competition seeing that UNIMARC or USMARC-based systems can be bought directly from overseas suppliers. This may have financial implications for South African companies.

Comparing the cost of the three scenarios it was found that both UNIMARC and USMARC implementation would be more costly than the retention of SAMARC. However, the 
operating cost of SAMARC will be substantially higher than the case would be for UNIMARC and USMARC. Calculating the total cost over the longer term for each scenario it was found that the total cost of running SAMARC will overtake the total cost of either scenario 2 or 3 already in the second year, and viewed over a period of ten years, SAMARC will be two and half times more costly than either of the other two formats (Snyman 1997:44).

\section{Recommendations}

After a thorough analysis of the information obtained during the investigation, it was recommended that, through a careful transition process SAMARC should be replaced by an international exchange format, preferably USMARC. The reasons for this recommendation were:

- The general movement away from the development of customized national formats. Libraries tend to use UNIMARC and USMARC as they are.

- The lack of an infrastructure for the maintenance and development of SAMARC and the cost involved in the creation of such an infrastructure.

- The markedly higher total cost of maintaining SAMARC in comparison with the alternative solution (UNIMARC or USMARC).

Although UNIMARC appeared to be the option with the lowest cost, the benefits in favour of USMARC would outweigh the slight cost advantage of UNIMARC. The reasons are:

- South African libraries are experiencing a decline in funding and have to cut back on original cataloguing. UNIMARC enjoys widespread support in Europe, Asia and parts of Latin America. However, the results of the questionnaire showed that the United States and United Kingdom are the countries from which South African libraries mostly obtained their information sources. Conversion programs also exist between UKMARC and USMARC and vice versa. When both the USEMarcon and OCLC projects have taken root, records in any MARC format may be available in USMARC format. It will be more cost-effective for South African libraries to copy records in USMARC format rather than to convert them to another format. Ultimately, original cataloguing will only be needed for some foreign publications and items published in South Africa.

- Although both UNIMARC and USMARC endeavour to keep pace with developments and requirements of the information community, USMARC is a more dynamic format. The concise versions of the USMARC formats are available on the Internet. USMARC also has a field for URLs to locate material on the Internet. UNIMARC is still far behind in this respect.

- Both UNIMARC and USMARC have a proper infrastructure for the revision and updating of their formats. However, the Permanent UNIMARC Committee in charge of the maintenance, revision and updating of the UNIMARC format meets only once a year. Proposals for changes to USMARC formats are submitted to joint meetings of MARBI and the USMARC Advisory Group at each ALA conference which takes place twice a year. Delays in the updating of SAMARC have created a sensitivity among South African librarians for regular updating of an exchange format.

- A need for the exchangeability of all the parts of the record, in other words the bibliographic record, authority record and holdings data, exists in South Africa. Although both UNIMARC and USMARC have bibliographic and authority formats, UNIMARC still lacks a format for holdings data.

- USMARC-based library and information systems are moving into the South African market. Some South African libraries and consortia are currently investigating (or have already decided on) an American system. Even in Europe support is in favour of USMARC-based systems.

- A need exists in South Africa for a core bibliographic record. USMARC serves as the basis for the development of prescribed bibliographic records for different types of library materials.

- There is lack of interest in Library of Congress records available in UNIMARC. The Library of Congress was involved in the development of UNIMARC in the early 1980s and provided records for customers in UNIMARC. There were never more than three customers for this service. After a while only one remained and now there is none (Barry 1997).

- South African libraries experience problems with authority files and quality control. In order to upgrade the quality of records on SACat, Sabinet Online has to take several actions, for example the matching of the interim records on SACat with the Library of Congress database to upgrade the records. Records available in USMARC will facilitate the outsourcing of the authority files cleanup operation, as fewer clean-up operations will be needed.

- Although the majority of the respondents to the questionnaire are using SAMARC, most favoured the adoption of USMARC.

The conversion to USMARC will not be without problems and difficulties. Problems which may be experienced include, among others:

- The adjustments regarding the authority and holdings files. Data in bibliographic files in SAMARC has to be placed in authority and holding files.

- Both SAMARC and USMARC follow the ISO 2709 standard. Thus the conversion of records from SAMARC to USMARC should not substantially affect the leader, directory or record identifier. With regard to the rest of the tagged fields, identifiers and indicators there are nevertheless important differences between SAMARC and USMARC which may cause problems during conversion.

- The investment in time and money for the retrospective conversion of records and the purchase of USMARC manuals may be quite substantial. 
- Format training will be required for which limited expertise exists in South Africa.

- In contrast to SAMARC and UNIMARC, which are specifically designed to handle multi-lingual materials, USMARC does not cater for the multi-lingual nature of the South African communities.

Various recommendations were made for the implementation of USMARC. These include among others the following:

- A steering committee should be established, consisting of representatives of all the stakeholders to give guidance during the transition period. A representative of a national library should chair the committee.

- A transition programme which will accommodate stakeholders' interests should be compiled by the steering committee. All the subsets of the transition process should be identified and entered in a guide-plan document for distribution.

- A MARC office should be established from where the transition and future MARC activities should be administered. The staff member of the MARC office should be co-opted on the steering committee to act as secretariat and administrative officer. The MARC office should also distribute a progress report on a regular basis to all concerned. For that purpose all stakeholders should provide the MARC office with feedback on progress on a regular basis. A help desk should also be established at the MARC office to provide information as well as channelling enquiries for expert advice.

- A ListServer should be established and hosted by Sabinet Online so that problems and progress could be discussed by all concerned.

- A conversion program for the conversion of SAMARC records to USMARC should be created. Sabinet Online should be responsible for the creation of the program, and the cost should be shared by Sabinet Online and all those utilizing the program.

- The conversion of local systems and databases to USMARC will have to take place. This should be the responsibility of the individual libraries and the system vendors. Cost should be borne by the libraries. It is also important that every library which utilizes SAMARC should plan to convert to USMARC with the guideplan mentioned above as directive.

- Sabinet Online should continue to exchange records in SAMARC format for an agreed-upon interim period while USMARC is being established. Sabinet Online, should in collaboration with its member libraries, define the interim period.

- A training programme for USMARC should be organized to ensure that as wide as possible a base of cataloguers become familiar with the new format. It was suggested that a representative group should firstly be trained by a USMARC expert, be it a person from the Network Development and MARC Standards Office of the Library of Congress or a competent local person trained in the United States.

\section{Seminar conclusion and decisions}

The recommendations of the research report for the adoption of USMARC as national exchange format has been accepted by the delegates of the seminar. The final conclusions were voted upon, and $76 \%$ of the delegates favour USMARC. While most delegates sensed the value of USMARC as the future exchange format for South Africa, some delegates were uneasy about change for no fundamental reason other than the uncertainty and cost of change.

In addition to the recommended implementation processes indicated in the research report, the delegates also felt that:

- The MARC office should be the only liaison office with the Network Development and MARC Standard Office of the Library of Congress.

- A national policy regarding USMARC fields which should be included or excluded in South African records, should be formulated.

Although some delegates felt that more time is needed to prepare the South African library and information community for a new format, the general feeling was that implementation should take place as soon as possible, as further delays will aggravate the existing gap between the South African and international information exchange possibilities. The longer the delay, the more the South African information community will find itself in turmoil as technology moves on.

\section{Conclusion}

The SAMARC format was originally developed in the light of the circumstances of the time and in the best interest of South Africa. However, circumstances have changed. The political transformation has led to the re-establishment of normal relations internationally. Participation internationally necessitates the utilization of an international exchange format.

The replacement of SAMARC with USMARC will take time and money, and will not be without difficulties. This, however, is only a matter of concern over the short term. Over the long term the benefits of opting for USMARC will outweigh the short-term concerns by far.

\section{Acknowledgement}

The financial assistance of the Department of Arts, Culture, Science and Technology towards this research and investigation is hereby acknowledged.

\section{References}

Barry, R.K. 1997. Letter of Mr K. Randall Barry, Network Development and MARC Standard Office, 21 January 1997.

Bruns, P. 1992. The USMARC community information format: a history and brief description. Information technology and libraries, (11):387-396. 
Campos, F.M., Lopes, M.I. \& Galvao, R.M. 1995. MARC formats and their use: an overview. Program, 29(4):445-459.

Coetzee, H.S. 1995. Opleiding van studente in katalogisering, klassifikasie en die verlening van onderwerpstoegang tot inligting. Suid-Afrikaanse tydskrif vir biblioteek- en inligtingkunde, 63(3): 148-158.

Furrie, B. 1994. Understanding MARC bibliographic. Washington, DC: Library of Congress.

Gredley, E. \& Hopkinson, A. 1990. Exchanging bibliographic data: $M A R C$ and other international formats. Ottowa: Canadian Library Association.

Guenther, R.S. 1994. The Library of Congress Classification in the USMARC format. Knowledge organization, 21(4):199-202.

Kokabi, M. 1995. The internationalization of MARC. Part 1, The emergence and divergence of MARC. Library review, 44(4):2135.

Kokabi, M. 1995. The internalionalization of MARC. Part IV, UNIMARC, some formats based on it and some other MARC formats. Library review, 44(7):8-32.

Leazar, G.H. 1992. An examination of data elements for bibliographic descriptions: toward a conceptual schema for the USMARC formats. Library resources \& technical services, 36(2): 189-206.

McKercher, B. \& Chang, P.X. 1995. A comparison of USMARC and UNIMARC for system design. International cataloguing \& bibliographic control, 21(2):21-25.

Majumder, U. 1992. Implementation of UNIMARC at India's national library. International cataloguing \& bibliographic control, 21(3):19-24.

Permanent UNIMARC Committee: terms of reference and procedures. 1992. International cataloguing \& bibliographic control, 21(4):51-52.

Snyman, M.M.M. 1997. Future MARC format for South African libraries: final report. Pretoria: Department of Arts, Culture, Science and Technology.

Varniené, R. 1995. UBC and the UNIMARC activities in Lithuania. International cataloguing \& bibliographic control, 24(1):9-11.

\section{Appendix Questionnaire}

With the exception of question 1 , mark your answer with an ' $x$ ' next to the appropriate option.

1. Indicate the name of your institution.
2. This question is aimed at establishing the country from which most of the information sources in your library/ information centre are currently obtained.

(a) Indicate the appropriate option

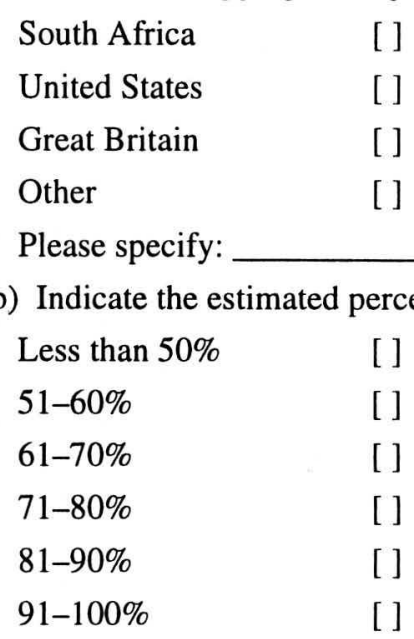

3. Mark the current exchange format utilized by your institution.

$\begin{array}{ll}\text { SAMARC } & {[]} \\ \text { UNIMARC } & {[]} \\ \text { USMARC } & {[]} \\ \text { Other } & {[]}\end{array}$

Please specify:

4. Do you regard a change from SAMARC as national exchange format to an alternative (UNIMARC, USMARC, etc.) as a necessity?

Yes

No

5. If so, to which exchange format?

$\begin{array}{ll}\text { UNIMARC } & {[]} \\ \text { USMARC } & {[]} \\ \text { Othor } & {[]}\end{array}$

Please specify: 